\title{
Analisis Penetapan Harga Jual Pembiayaan Murabahah pada Lembaga Keuangan Syariah Bank dan Non Bank
}

\author{
Lailatul Sikrillah
}

\author{
Accounting Department, Faculty of Economy \\ Maulana Malik Ibrahim, State Islamic University of Malang, \\ Indonesia
}

\begin{abstract}
This study aims to determine the selling price of murabaha financing application and calculation of profit margins on BRISyariah, BPRS Bumi Rinjani and UJKS El-Dinar. The research method used is a qualitative research method with a descriptive approach. Where data is the primary data obtained in the form of interviews with the parties concerned and secondary data in the form of data processing can be accounted for from a reliable source to conduct library research, interviews and internet. The results of this study found that setting the selling price on BRISyariah murabahah financing, BPRS Bumi Rinjani and UJKS ElDinar that use the same basic price plus a profit margin. As for determining the profit margin that the bank sets its own and equally consider five factors determining the margin is the profit margin on average Islamic bank (Direct Competitor's Market Rate/DCMR), the interest rate the average conventional banks (Indirect Competitor's Market Rate/ICMR), the results of third-party funds (Competitive Expected Return for Investors/ECRI), Overhead Cost, profit targets taking into account inflation and interest rate markets. In a benefit margin calculations using a flat (fixed).
\end{abstract}

Keywords: Murabahah, Determination of Selling Price, Margin Calculation System Advantage.

\section{PENDAHULUAN}

Menurut Andri (2009:72) Bank syariah yang terdiri dari BUS, UUS serta BPRS, pada dasarnya melakukan kegiatan usaha yang sama dengan bank konvensional, yaitu melakukan penghimpunan dan penyaluran dana masyarakat disamping penyediaan jasa keuangan lainnya. Perbedaannya adalah seluruh kegiatan Bank Umum Syariah (BUS), Unit Usaha Syariah (UUS) dan Bank Pembiayaan Rakyat Syariah (BPRS) didasarkan pada prinsip 
syariah. Implikasinya, jasa keuangan tersebut sesuai dengan prinsip hukum Islam dan memiliki berbagai variasi akad yang akan menimbulkan variasi produk yang lebih banyak dibandingkan produk bank konvensional.

Bank syariah di Indonesia sejak tahun 2000 telah menjadi satu industri keuangan yang sedang tumbuh berkembang dan menarik perhatian investor dan masyarakat. Perkembangan bank syariah untuk saat ini di Indonesia hanya sebatas pada bertambahnya Bank Umum Syariah (BUS) dan Unit Usaha Syariah (UUS), tidak diimbangi dengan berkembangnya market share-nya. (Suprayogi :2013)

Bank syariah di Indonesia mulai berdiri pada tahun 1992. Dari jumlah entitas usaha, berdasarkan data Bank Indonesia, saat ini terdapat 11 Bank Umum Syariah (BUS), 24 bank syariah dalam bentuk Unit Usaha Syariah (UUS), dan 156 Bank Pembiayaan Rakyat Syariah (BPRS). Data pertumbuhan dan struktur perbankan syariah memperlihatkan daya tahan di tengah gejolak pasar keuangan global. Hingga Juni 2013 pertumbuhan aset perbankan syariah mencapai 40,64 persen, meningkat dari Rp155,41 triliun pada 2012 menjadi Rp218,57 triliun pada 2013. (Firmanzah : 2013).

Secara kuantitas, pencapaian perbankan syariah sungguh membanggakan dan terus mengalami peningkatan dalam jumlah bank. Jika pada tahun 2005 hanya ada tiga Bank Umum Syariah (BUS) dan 95 Bank Pembiayaan Rakyat Syariah (BPRS), maka pada Januari 2012 (berdasarkan data Statistik Perbankan Syariah yang dipublikasikan oleh Bank Indonesia) jumlah bank syariah telah mencapai 35 unit yang terdiri atas 11 Bank Umum Syariah (BUS) dan 24 Unit Usaha Syariah (UUS). Selain itu, jumlah Bank Pembiayaan Rakyat Syariah (BPRS) telah mencapai 155 unit pada periode yang sama.

Salah satu produk perbankan syariah adalah pembiayaan. Seperti yang dikatakan oleh Muhammad (2005:16-17) bahwasanya dalam aktivitasnya bank syariah akan menjalankan beberapa teknik dan metode yang penerapannya tergantung pada tujuan dan aktivitas. Pertumbuhan setiap bank menurut Zainul (2002) pasti akan dipengaruhi oleh perkembangan kemampuannya dalam menghimpun dana masyarakat dengan memberlakukan sistem nilai dan etika Islam kedalam lingkungan ekonomi. Selanjutnya, untuk mencapai sebuah tujuan tersebut, bank harus bisa mengarahkan pengalokasian dana sedemikian rupa agar semua kepentingan nasabah dapat terpenuhi. Tingkat penghasilan 


\section{Analisis Penetapan Harga Jual Pembiayaan Murabahah}

tertinggi bank adalah melalui pembiayaan, maka dari itu portofolio pembiayaan menempati porsi terbesar sekitar $50-60 \%$ dari total aktiva.

Pembiayaan yang paling dominan dalam perbankan syariah adalah pembiayaan murabahah. Karim (2006:113) dan Makhalul (2002:38-39) menyimpulkan bahwasanya murabahah merupakan salah satu produk penyaluran dana yang cukup digemari oleh masyarakat.

Perbankan syariah dalam menentukan kebijakan harga jual yang diinginkan tidaklah terlepas dari rujukan kepada suku bunga konvensional, tingkat pesaing (competitor) dan sebagainya. Penentuan harga merupakan salah satu aspek penting dalam kegiatan pemasaran. Harga menjadi sangat penting untuk diperhatikan mengingat harga sangat menentukan laku tidaknya produk dan jasa perbankan. Apabila terdapat kesalahan dalam menentukan harga maka akan berakibat fatal terhadap produk yang ditawarkan. Dengan mempertimbangkan hal-hal tersebut, maka dalam penentuan harga jual murabahah adalah penjumlahan harga beli/harga perolehan/harga pokok ditambah dengan marjin keuntungan.

Berbicara masalah marjin keuntungan dalam pembiayaan murabahah, kita sebagai umat Islam masih sering bertanya-tanya. Tetapi satu hal yang harus kita ingat bahwa murabahah merupakan jual beli, dimana jual beli memang dianjurkan dalam Islam dan jika melakukan transaksi jual beli sudah pasti pihak penjual akan mengambil keuntungan dari transaksi tersebut. Walaupun dibolehkan, dalam pengambilan keuntungan tersebut tidak boleh melebihi batas yang telah disyariatkan oleh Islam. Sedangkan menurut beberapa ulama menyimpulkan bahwa jual beli murabahah sah menurut hukum walaupun tidak mempunyai rujukan atau referensi langsung dari $A l-Q u r^{\prime} a n$ maupun Sunnah. Jual beli murabahah merupakan jual beli amanah, karena pembeli memberikan amanah kepada penjual untuk memberitahukan harga pokok barang tanpa bukti tertulis. (Ubay Harun, 2006).

Dalam menentukan target konsumen di Bank Umum Syariah (BUS), Bank Pembiayaan Rakyat Syariah (BPRS) dan Unit Jasa Keuangan Syariah (UJKS) tentunya berbeda karena disetiap lembaga keuangan syariah memiliki aturan dan penentuan target yang tidak sama, mungkin jika di Bank Umum Syariah (BUS) target konsumen lebih besar dari pada Bank Pembiayaan Rakyat Syariah (BPRS) dan Unit Jasa Keuangan Syariah (UJKS). Perbedaan tersebut 
juga dapat dilihat dalam organisasi dan modal yang digunakan, jika semakin besar organisasi dan modalnya maka semakin besar pula target konsumennya. Tetapi dalam menentukan penerapan akad murabahah pada produk-produk yang ditawarkan tidak ada bedanya, karena sama-sama menerapkan penjanjian antara bank dengan nasabah, dimana bank menyediakan pembiayaan untuk pembelian bahan baku atau modal kerja yang dibutuhkan nasabah serta yang akan dibayar kembali oleh nasabah sebesar harga jual bank (harga beli bank plus margin keuntungan saat jatuh tempo). (Icanende :2010)

Penelitian dengan topik murabahah telah banyak dilakukan, namun yang memfokuskan pada penerapan pembiayaan murabahah adalah Adi (2005) yang meneliti tentang Faktor-faktor yang Mempengaruhi Margin Keuntungan Pembiayaan Murabahah pada Bank Muamalat Indonesia didapati bahwa biaya overhead dan bagi hasil Dana Pihak Ketiga (DPK) mempengaruhi margin pembiayaan murabahah serta volume pembiayaan dan profit target tidak sesuai terhadap margin pembiayaan murabahah. Sedangkan penelitian yang meneliti dari sisi penetapan harga jual murabahah adalah Firmansyah (2007) yang meneliti tentang Evaluasi Penetapan Metode Penentuan Harga Jual Beli Murabahah pada BMT Berkah Madani didapati bahwa dalam menentukan harga jual belum sempurna dengan aturan syariah karena masih menggunakan prinsip konvensional. Nurul (2008) juga mengungkap bahwa Penerapan Pembiayaan pada BPRS Bumi Rinjani Batu telah sesuai dengan standart yang ada dalam teori serta fatwa MUI, namun masih ada kendala pada penggunaan akad. Selanjutnya Achmad (2011) yang meneliti tentang Evaluasi Penetapan Metode Penentuan Harga Jual Beli Murabahah pada BMT Prima Murabahah Syariah telah didapati bahwa penentuan harga jual beli pembiayaan murabahah dengan memasukkan variabel-variabel yang, seharusnya secara syariat tidak diperbolehkan, karena menimbulkan efek tingginya harga jual beli pembiayaan murabahah.

Berdasarkan penelitian sebelumnya, belum ada yang meneliti tentang penetapan harga jual murabahah pada BUS, BPRS dan BMT. Maka peneliti menfokuskan pada Analisis Penetapan Harga Jual Pembiayaan Murabahah Pada Lembaga Keuangan Syariah Bank dan Non Bank, StudI pada PT Bank BRISyariah Cabang Pembantu Kepanjen-Malang, PT BPRS Bumi Rinjani Kepanjen dan UJKS El-Dinar Malang. 
Definisi Bank Syariah, Bank Pembiayaan Rakyat Syariah (BPRS) dan Unit Jasa Keuangan Syariah (UJKS)

Bank adalah lembaga perantara keuangan atau biasa disebut financial intermediary. Artinya, lembaga bank adalah lembaga yang dalam aktivitasnya berkaitan dengan masalah uang. Oleh karena itu, usaha bank akan selalu dikaitkan dengan masalah uang yang merupakan alat pelancar terjadinya perdagangan yang utama. Kegiatan dan usaha bank akan selalu terkait dengan komoditas, antara lain memindahkan uang, menerima dan membayarkan kembali uang nasabah, membeli dan menjual suratsurat berharga, dan memberi jaminan bank. (Muhammad, 2005:1)

Bank syariah adalah bank yang dalam menjalankan usahanya berdasarkan pada prinsip-prinsip syariah Islam. Bank syariah yang disebut pula dengan bank Islam adalah bank yang beroperasi dengan tidak mengandalkan pada bunga. Bank syariah juga dapat diartikan sebagai lembaga keuangan/perbankan yang operasional dan produknya dikembangkan berlandaskan $\mathrm{Al}$ Qur'an dan hadist.

Antonio dan Perwatmadja dalam Sulhan (2008:125) menyatakan bahwa ada dua pengertian, yaitu Bank Islam dan bank yang beroperasi dengan prinsip syariah. Bank Islam adalah bank yang beroperasi dengan prinsip syariah Islam dan bank tata cara beroperasinya mengacu kepada ketentuan-ketentuan $A l-Q u r^{\prime} a n$ dan Al-Hadist. Bank yang beroperasi sesuai dengan prinsip syariah Islam adalah bank yang dalam operasinya mengikuti ketentuanketentuan syariah Islam, khususnya yang menyangkut tata cara bermuamalat secara Islami.

\section{Pembiayaan Murabahah}

Pembiayaan (financing) yaitu pendanaan yang diberikan oleh suatu pihak kepada pihak lain untuk mendukung investasi yang telah direncanakan, baik dilakukan sendiri maupun lembaga. Dengan kata lain, pembiayaan adalah pendanaan yang dikeluarkan untuk mendukung investasi yang telah direncanakan.

Tujuan dari pembiayaan adalah untuk meningkatkan ekonomi umat, tersedianya dana bagi peningkatan usaha, meningkatkan produktivitas, membuka lapangan kerja baru, dan distribusi pendapatan. Pembiayaan dalam kategori mikro adalah untuk upaya memaksimalkan laba, meminimalkan risiko, 
pendayagunaan sumber ekonomi, dan penyaluran kelebihan dana. Jadi, tujuan utama adalah memenuhi kepentingan stakeholder.

Fungsi dari pembiayaan adalah meningkatkan daya guna uang, meningkatkan daya guna barang, meningkatkan peredaran uang, menimbulkan kegairahan berusaha, stabilitas ekonomi, sebagai jembatan untuk meningkatkan pendapatan nasional. (Muhammad, 2005 : 17-21)

Menurut Al-muslih dan Ash-shawi (2004) Murabahah secara bahasa adalah bentuk mutual (bermakna saling) dari kata Ribh yang artinya keuntungan, yakni pertambahan nilai modal (jadi artinya saling mendapatkan keuntungan). Menurut terminology ilmu fiqih artinya murabahah adalah mnjual dengan modal asli bersama tambahan keuntungan yang jelas.

Murabahah adalah transaksi penjualan barang dengan menyatakan harga perolehan dan keuntungan yang disepakati oleh penjual dan pembeli. Dimana penjual harus memberitahu harga produk yang dibeli dan menentukan suatu tingkat keuntungan sebagai tambahannya.

\section{Tinjauan Penentuan Harga Jual Menurut Syariah}

Menurut Bank Indonesia pada suatu transaksi jual beli yang ideal, bank syariah harus dapat menghitung dan memisahkan "real costs" dan tingkat keuntungan yang diinginkan oleh bank sebagai dasar penetapan marjin. Demikian pula pada transaksi investasi, suatu bank syariah harus dapat menentukan tingkat keuntungan berdasarkan kinerja keuangan yang nyata dari suatu perusahaan. Namun demikian, pada kenyataannya marjin keuntungan pada transaksi jual beli masih di benchmark terhadap tingkat suku bunga karena belum adanya basis data tentang benchmark biaya perolehan dan handling kelompok-kelompok komoditas yang akurat sebagai indikator penetapan marjin keuntungan. Demikian pula pada transaksi investasi, belum tersedianya benchmark yang dapat menggambarkan proyeksi profitabilitas bidang usaha serta belum tersedianya metode perhitungan standar atas biaya-biaya yang dapat diperhitungkan dalam penentuan bagi hasil, mengakibatkan bank mengambil benchmark yang secara prinsip tidak mengindikasikan tingkat produktivitas nyata jenis usaha. (Buchori : 2004)

\section{Penetapan Marjin Keuntungan}

Bank syariah menetapkan marjin keuntungan terhadap produk-produk pembiayaan yang berbasis Natural Certainty Contracts (NCC), yakni akad bisnis yang memberikan kepastian 
pembayaran, baik dari segi jumlah (amount) maupun waktu (timing), seperti pembiayaan murabahah, ijarah muntahia bit tamlik, salam dan istishna'.

Secara teknis, yang di maksud dengan margin keuntungan adalah persentase tertentu yang ditetapkan per tahun perhitungan marjin keuntungan secara harian, maka jumlah hari dalam setahun ditetapkan 360 hari, perhitungan marjin keuntungan secara bulanan, maka setahun ditetapkan 12 bulan.

Pada umumnya, nasabah pembiayaan melakukan pembayaran secara angsuran. Tagihan yang timbul dari transaksi jual beli dan atau sewa berdasarkan akad murabahah, salam, istishna' dan atau ijarah disebut sebagai piutang. Besarnya piutang tergantung pada plafond pembiayaan, yakni jumlah pembiayaan (harga beli ditambah harga pokok) yang tercantum di dalam perjanjian pembiayaan. (karim : 2004)

Referensi Marjin Keuntungan

Menurut Karim (2004) yang dimaksud dengan Referensi Marjin Keuntungan adalah marjin keuntungan yang ditetapkan dalam rapat ALCO (Asets Liabilities Management Committee) Bank Syariah. Penetapan marjin keuntungan pembiayaan berdasarkan rekomendasi, usul dan saran dari tim ALCO Bank Syariah, dengan mempertimbangkan beberapa hal:

1) Direct Competitor's Market Rate (DCMR)

2) Indirect Competitor's Market Rate (ICMR)

3) Expected Competitive Return for Investors (ECRI)

4) Acquiring Cost

5) Overhead Cost

6) Cost of Loanable Fund (biaya peminjaman dana atau biaya yang dikeluarkan).

7) Keuntungan yang diinginkan (Profit Target)

\section{METODOLOGI PENELITIAN}

Jenis penelitian ini merupakan jenis penelitian kualitatif yaitu berupa suatu prosedur penelitian yang menghasilkan data deskriptif berupa ucapan atau tulisan dari perilaku yang dapat diamati dari subjek itu sendiri. (Furhan, 1992:21).

Dengan pendekatan ini diharapkan dapat dilakukan suatu pengujian secara rinci terhadap suatu latar, suatu tempat penyimpanan dokumen atau satu peristiwa tertentu karena merupakan penelitian studi kasus. Dalam penelitian ini, studi kasus dilakukan untuk meneliti tentang penetapan harga jual 
murabahah beserta perhitungaan marjin keuntungan pada BRISyariah Cabang Pembantu Kepanjen-Malang, Bank Pembiayaan Rakyat Syariah (BPRS) Bumi Rinjani Kepanjen-Malang dan Unit Jasa Keuangan Syariah (UJKS) El-Dinar Malang.

HASIL PENELITIAN

Analisis Penetapan Harga Jual Pembiayaan Murabahah pada PT. Bank BRISyariah Kantor Cabang Pembantu Kepanjen-Malang

Berdasarkan hasil wawancara dengan Dita (Account Officer) tentang harga jual pembiayaan murabahah menyatakan bahwa: "Di BRISyariah harga jual pembiayaan di tentukan oleh bank yaitu dengan menentukan harga beli ditambah dengan margin yang ditentukan oleh pihak bank".Adapun rumus untuk menentukan harga jual yang ada di BRISyariah sebagai berikut:

$$
\text { Harga Jual = Harga Beli + Margin }
$$

Sumber: Data hasil wawancara dengan Dita Account Officer BRIS (4 Maret 2014

$$
\text { pukul } 09.00 \text { wib) }
$$

Metode penetapan harga jual murabahah yang dilakukan oleh BRISyariah adalah menggunakan metode keuntungan flat (tetap) dimana perhitungan marjin keuntungan terhadap nilai harga pokok pembiayaan secara tetap dari satu periode keperiode lainnya, walaupun baki debetnya (saldo pokok dari plafond pinjaman yang telah disepakati dalam perjanjian kredit) menurun sebagai akibat dari adanya angsuran harga pokok.

Adapun metode flat (tetap) perhitungan angsuran pokok per bulan sebagai berikut:

Angsuran per bulan $=$ Plafond + Margin $\times$ Jangka Waktu Per Tahun

$$
\text { Jangka Waktu Per Bulan }
$$

Sumber: Data hasil wawancara dengan Dita Account Officer BRIS (4 Maret 2014 pukul 09.00 wib)

Berikut ini perhitungan untuk penetapan harga jual pembiayaan murabahah yang ada di BRISyariah:

Jenis pembiayaan pembiayaan apa yang mau di ajukan oleh nasabah kepada

Harga beli BRISyariah

Harga yang di keluarkan oleh pihak penjual (developer)

Margin Keuntungan bank (selisih antara harga jual dikurangi margin)

Harga jual Harga beli ditambah margin yang ditentukan pihak bank

Uang muka Uang yang di bayarkan oleh nasabah kepada pihak penjual 


\begin{tabular}{|c|c|}
\hline & (developer) \\
\hline $\begin{array}{l}\text { Harga jual yg } \\
\text { diangsur }\end{array}$ & $\begin{array}{l}\text { Total dari porsi pembiayaan bank di tambah margin yang } \\
\text { diangsur oleh nasabah }\end{array}$ \\
\hline Plafon & Besarnya jumlah pembiayaan yang di setujui / ACC oleh bank \\
\hline Angsuran perbulan & Angsuran yang wajib dibayarkan oleh nasabah tiap bulannya \\
\hline Administrasi & Biaya 1\% dari plafond yang disetujui / ACC oleh bank \\
\hline Biaya Notaris & $\begin{array}{l}\text { Biaya yang di keluarkan untuk notaris yang meliputi biaya } \\
\text { legalitas akad, cek sertifikat di BPN (Badan Pengawas } \\
\text { Nasional), SKMHT (Surat Kuasa Membebankan Hak } \\
\text { Tangguhan) / APHT (Akta Pemasaran Hak Tangguhan) }\end{array}$ \\
\hline $\begin{array}{lr}\text { Akta } & \text { Pemasaran } \\
\text { Hak Tanggungan } \\
\text { (APHT) }\end{array}$ & $\begin{array}{l}\text { Untuk } \geq 50 \text { juta SKMHT (Surat Kuasa Pembeban Hak } \\
\text { Tanggungan) 5maksudnya tarif yang digunakan sesuai } \\
\text { dengan plafond pembiayaan }\end{array}$ \\
\hline Biaya materai & Biaya untuk pembelian materai sebanyak 6 buah @ Rp.6000,- \\
\hline $\begin{array}{l}\text { Buka Rekening } \\
\text { Tabungan }\end{array}$ & Biaya untuk membuka rekening baru sebesar Rp. 50.000 ,- \\
\hline Premi Asuransi Jiwa & $\begin{array}{l}\text { Biaya yang dikeluarkan berdasarkan umur nasabah dan } \\
\text { ditentukan dengan menggunakan rumus yang ditetapkan oleh } \\
\text { perusahaan }\end{array}$ \\
\hline $\begin{array}{l}\text { Premi Asuransi } \\
\text { Kebakaran }\end{array}$ & $\begin{array}{l}\text { Biaya yang dikeluarkan berdasarkan rumah nasabah dan } \\
\text { ditentukan dengan menggunakan rumus yang ditetapkan oleh } \\
\text { perusahaan }\end{array}$ \\
\hline $\begin{array}{l}\text { Dana mengendap } \\
\text { (Blokir } \quad 1 x \\
\text { Angsuran) } \\
\end{array}$ & Sesuai dengan jumlah angsuran setiap bulannya \\
\hline
\end{tabular}

Berdasarkan penjelasan analisis tentang penetapan harga jual pembiayaan murabahah pada PT. Bank Rakyat Indonesia Syariah (BRISyariah) ini ada pendapat yang menjelaskan tentang teori harga jual. Menurut ilmu ekonomi harga jual merupakan jumlah tertentu yang dibayarkan oleh konsumen (nasabah) terhadap barang atau jasa yang diterima. Sedangkan di BRISyariah sendiri menerapkan harga jual dari perhitungan harga beli atau pokok ditambahkan oleh marjin keuntungan yang ditentukan oleh pihak bank.

\section{Analisis Penetapan Harga Jual Pembiayaan Murabahah pada PT. Bank Pembiayaan Rakyat Syariah (BPRS) Bumi Rinjani Kepanjen-Malang}

Dari hasil wawancara dengan Fany (Administrasi Pembiayaan) tentang harga jual pembiayaan murabahah menyatakan bahwa: "Di BPRS Bumi Rinjani ini penetapan harga jual pembiayaan murabahah itu ditentukan dari harga pokok ditambah dengan margin yang ditetapkan oleh pihak BPRS Bumi Rinjani... kemudian akan ditemukan sisa piutang dari harga jual tersebut yang dikurangi dengan uang muka (urbun)". Adapun rumus untuk 
menentukan harga jual yang ada di BPRS Bumi Rinjani sebagai berikut:

$$
\begin{aligned}
& \text { Harga Jual = Harga Pokok + Margin } \\
& \text { Sisa Piutang = Harga Jual - Uang Muka (Urbun) }
\end{aligned}
$$

Sumber : Dari hasil wawancara dengan Fany (Administrasi Pembiayaan) tanggal 4 maret 2014 (pukul 08.30 wib)

Metode penetapan harga jual murabahah yang dilakukan oleh BPRS Bumi Rinjani adalah menggunakan metode keuntungan flat (tetap) dimana perhitungan marjin keuntungan terhadap nilai harga pokok pembiayaan secara tetap dari satu periode keperiode lainnya, walaupun baki debetnya (saldo pokok dari plafon pinjaman yang telah disepakati harga pokok.

Adapun metode flat (tetap) perhitungan angsuran pokok per bulan sebagai berikut:

Angsuran per bulan $=$ Plafond $\mathbf{x}$ Margin $\mathbf{x}$ Jangka Waktu

Sumber : Dari hasil wawancara dengan Fany (Administrasi Pembiayaan) tanggal 4 maret 2014 (pukul 08.30 wib)

Berikut ini perhitungan untuk penetapan harga jual pembiayaan murabahah yang ada di BPRS Bumi Rinjani:

Jenis Pembiayaan Pembiayaan apa yang mau di ajukan oleh nasabah kepada BPRS Bumi Rinjani

Harga Pembelian Harga yang dikeluarkan oleh pihak penjual

Margin Bank Jumlah harga pembelian yang dikalikan dengan $40 \%$ dari harga

beli

Harga Jual Harga pokok yang ditambah dengan margin

Uang Muka (urbun) Uang yang akan dibayarkan nasabah ke pihak penjual

Saldo Hutang Nilai dari harga jual yang dikurangi dengan uang muka

Jangka Waktu Jumlah hari yang ditentukan untuk penentuan pembiayaan

Angsuran Per bulan Angsuran yang wajib dibayarkan oleh nasabah

Biaya Administrasi Biaya 1\% dari plafond pembiayaan

Biaya Notaris

Premi Asuransi

Biaya yang dikeluarkan untuk notaris

Biaya Materai

Biaya yang dikeluarkan untuk asuransi jiwa

Biaya yang dikeluarkan untuk pembelian materai

Berdasarkan penjelasan analisis tentang penetapan harga jual pembiayaan murabahah pada BPRS Bumi Rinjani ini ada pendapat 
yang menjelaskan tentang teori harga jual. Menurut mulyadi (2001) harga jual pada prinsipnya harus dapat menutupi biaya penuh ditambah dengan laba yang wajar. Sedangkan di BPRS Bumi Rinjani sendiri menetapkan harga jual sebagai harga yang didapati dari harga pokok ditambah marjin yang ditentukan oleh pihak bank.

Analisis Penetapan Harga Jual Pembiayaan Murabahah pada Unit Jasa Keuangan Syariah (UJKS) El-Dinar Malang

Berdasarkan hasil wawancara dengan Yuke (Account Officer) tentang harga jual pembiayaan murabahah menyatakan bahwa: "Di UJKS El-Dinar harga jual pembiayaan di tentukan oleh bank yaitu dengan menentukan plafond (harga pokok) ditambah dengan margin dibagi dengan jangka waktu per bulannya". Adapun rumus untuk menentukan harga jual yang ada di UJKS ElDinar sebagai berikut:

$$
\text { Harga Jual }=\frac{\text { Plafond (Harga Pokok) }+ \text { margin }}{\text { Jangka Waktu (bulan) }}
$$

Sumber: Dari hasil wawancara Yuke (Account Officer) UJKS El-Dinar tanggal 27 feb 2014 (pukul 11.00 wib)

Metode penetapan harga jual murabahah yang dilakukan oleh UJKS El-Dinar Malang adalah menggunakan metode keuntungan flat (tetap) dimana perhitungan marjin keuntungan terhadap nilai harga pokok pembiayaan secara tetap dari satu periode keperiode lainnya, walaupun baki debetnya (saldo pokok dari plafond pinjaman yang telah disepakati dalam perjanjian kredit) menurun sebagai akibat dari adanya angsuran harga pokok. Adapun metode flat (tetap) perhitungan angsuran pokok per bulan sebagai berikut:

$$
\text { Angsuran per bulan }=\frac{\text { Margin } \times \text { Jangka Waktu } \times \text { Jumlah Pembiayaan }}{100}
$$

Sumber: Dari hasil wawancara Yuke (Account Officer) UJKS El-Dinar tanggal 27 feb 2014 (pukul 11.00 wib)

Berikut ini perhitungan untuk penetapan harga jual pembiayaan murabahah yang ada di UJKS El-Dinar: 
Jenis

Pembiayaan

Harga Beli

Margin

Harga Jual

Jangka Waktu

Grace Periode

Dropping

Margin Flat

Biaya

Administrasi

Biaya Materai

Biaya Notaris
Pembiayaan apa yang mau di ajukan oleh nasabal kepada UJKS El-Dinar

Harga yang dikeluarkan oleh pihak penjual (developer)

Keuntungan bank (selisih antara harga jual dikurangi margin)

Harga pokok ditambah dengan margin kemudian dibagi jangka waktu per bulannya

Jumlah hari yang ditentukan untuk penentuan pembiayaan

Kelonggaran waktu dalam pembayaran kembali angsuran pinjaman pokok dan atau bunga yang disepakati oleh kedua pihak

Pencairan (Realisasi) pembiayaan yang telah disetujui dalam kesepakatan oleh kedua pihak

Selisih tetap yang ditetapkan oleh UJKS El-Dinar yaitu $21 \%$ per

Biaya 1\% dari plafond pembiayaan

Biaya yang dikeluarkan untuk pembelian materai Biaya yang dikeluarkan untuk notaris

Berdasarkan penjelasan analisis tentang penetapan harga jual pembiayaan murabahah pada UJKS El-Dinar ini ada beberapa pendapat yang menjelaskan tentang teori harga jual. Menurut Mulyadi (2005) harga jual adalah besarnya harga yang akan dibebankan kepada konsumen yang diperoleh atau dihitung dari biaya produksi ditambah biaya non produksi dan laba yang diharapkan. Tapi menurut yang diterapkan di UJKS El-Dinar harga jual tersebut harga akan dibebankan kepada nasabah yang diperoleh dari pembiayaan.

KESIMPULAN

Dalam penetapan harga jual pembiayaan murabahah, pihak bank BRISyariah, BPRS Bumi Rinjani dan UJKS El-Dinar belum sesuai dengan prinsip syariah. Karena dalam penerapannya belum memenuhi persyaratan dan masih menggunakan rumus penetapan harga jual yang diterapkan pada bank konvensional. BRISyariah, BPRS Bumi Rinjani dan UJKS El-Dinar sama-sama menetapkan harga beli ditambah marjin keuntungan yang ditentukan oleh pihak bank. Adapun metode penetapan harga jual pembiayaan murabahah yang digunakan oleh bank BRISyariah, BPRS Bumi Rinjani dan UJKS El-Dinar dengan metode flat (tetap) yaitu marjin 


\section{Analisis Penetapan Harga Jual Pembiayaan Murabahah}

keuntungan terhadap nilai harga pokok pembiayaan secara tetap dari periode 1 ke periode lainnya, walau baki debet menurun yang disebabkan oleh angsuran harga pokok.

Dalam proses merumuskan penetapan marjin keuntungan, pihak bank BRISyariah, BPRS Bumi Rinjani dan UJKS El-Dinar mempertimbangkan beberapa hal yaitu seperti marjin keuntungan bank syariah lain (Direct Competitor's Market Rate / DCMR), suku bunga bank konvensional (Indirect Competitor's Market Rate / ICMR), bagi hasil dana pihak ketiga (Expected Competitive Return fot Investors / ECRI), biaya overhead yang meliputi biaya administrasi, biaya asuransi kebakaran dan asuransi jiwa, keuntungan yang diinginkan dengan mempertimbangkan tingkat inflasi dan suku bunga pasar. Tetapi semua pertimbangan tersebut tetap berpegang teguh pada ketentuan yang ditetapkan oleh kantor pusat dan tidak boleh keluar dari ketentuan yang telah ditetapkan. Dalam penerapannya pihak bank akan selalu menyeimbangkan dengan keadaan perbankan di Indonesia. Maka bank BRISyariah, BPRS Bumi Rinjani dan UJKS El-Dinar mempertimbangkan beberapa hal yaitu, marjin keuntungan bank semaksimal mungkin menerapkan produk yang benar-benar memenuhi kebutuhan masyarakat kalangan menengah ke bawah dengan produk sistem jual beli murabahah. Penentuan marjin keuntungan didasarkan pada besarnya plafond pembiayaan dan jangka waktu yang ditetapkan pada awal akad. Semakin besar plafond yang diberikan maka semakin kecil marjin keuntungan yang ditetapkan, dan sebaliknya jika semakin kecil plafond pembiayaan maka semakin besar marjin keuntungan yang ditetapkan. Marjin keuntungan yang biasanya dinyatakan dalam persentase tersebut memang telah ditetapkan oleh kantor pusat. Akan tetapi, pada Bank BRISyariah, BPRS Bumi Rinjani dan UJKS El-Dinar yang berwenang menetapkan marjin keuntungan adalah manajer dengan berdasarkan besarnya plafond pembiayaan yang diberikan kepada nasabah.

\section{SARAN}

Bank BRISyariah, BPRS Bumi Rinjani dan UJKS El-Dinar tidak membebankan biaya overhead, cost of loanable fund dan profit target dalam menentukan harga jual murabahah. Dalam penetapan marjin keuntungan, diharapkan bank BRISyariah, BPRS Bumi Rinjani dan UJKS El-Dinar berlandaskan pada tiga faktor utama yang sesuai dengan prinsip syariah, yaitu harga dasar pembelian dari penyalur utama, biaya yang harus tertutupi dan keuntungan wajar yang disepakati oleh pihak bank dan nasabah. 
Mengembangkan transaksi sesuai kebutuhan nasabah tetapi tetap berpegang teguh pada prinsip-prinsip syariah. Bagi peneliti selanjutnya disarankan untuk menambah fokus penelitian penetapan marjin keuntungan pada transaksi syariah lainnya, misalnya pada akad musyarakah dan mudharabah, dan melakukan komparasi penetapan marjin keuntungan pada akad syariah yang berbeda.

DAFTAR PUSTAKA

Al-Muslih, Abdullah, dan Ash-Shawi, Shalah. 2004. Fikih Ekonomi Keuangan Islam. Jakarta : Darul-Haq.

Al-Qur'an dan Al-Hadist.

Anam, Khoirul. 2009. Analisis Praktek Pembiayaan Murabahah. Skripsi. Semarang : FE IAIN Semarang.

Antonio, Syafi'I, Muhammad. 1999. Bank Syariah Bagi Bankir dan Praktek Keuangan.Cetakan Pertama. Jakarta : Bank IndonesiaTazkia.

Buchori, Ahmad, dkk. 2004. Standarisasi Akad Perbankan Syariah. Jakarta : Bank Indonesia.

Fauzan, Achmad. 2011. Pembiayaan Bermasalah Evaluasi Penetapan MetodePenentuan Harga Jual Beli Murabahah. Skripsi. Jakarta : FE UIN Jakarta.

Firmansyah. 2007. Evaluasi Penetapan Metode Penentuan Harga Jual Beli Murabahah. Skripsi. Jakarta : STEI SEBI.

Firmanzah. Pada 18 November 2013. Dalam http://www.economy.okezone.com. Diunduh pada

10 Januari 2014

Hadad, Muliaman. Pada 27 Juni 2013. Dalam http://www.kompas.com. Diunduh pada 10 Januari 2014.

Harun, Ubay. 2006. Murabahah Dalam Perspektif Figh dan Sistem Perbankan Islam HukumIslam, Vol. 5 (3): 347-349.

Hidayati, Nurul. 2008. Evaluasi Penerapan Pembiayaan Murabahah. Skripsi. Malang : FE UIN Malang.

Icanende. Pada 28 November 2010. Dalam http://acankende.wordpress.com. Diunduh pada 11 Desember 2013

Idrus, Muhammad. 2009. Metode Penelitian Ilmu Sosial Pendekatan Kualitatif dan Kuantitatif. Edisi kedua. Yogyakarta: Penerbit Erlangga.

Ilmi, Makhalul. 2002. Teoridan Praktek Lembaga Mikro Keuangan Syariah. Yogyakarta : UII Press. 
Analisis Penetapan Harga Jual Pembiayaan Murabahah

Karim, Adiwarman. 2004. Bank Islam :Analisis Fiqih dan Keuangan. Edisi kedua, Jakarta: Kharisma Putra Utama Offset.

Karim, Adiwarman. 2008. Fikih Ekonomi Keuangan Islam. Edisi kedua, Jakarta : Darul-Haq.

Kasmir. 2003. Manajemen Perbankan. Cetakan Keempat. Jakarta : PT. Raja Grafindo Persada.

Muhammad. 2005. Manajemen Pembiayaan Bank Syariah. Yogyakarta: Unit Penerbit dan Percetakan YKPN.

Mulyadi. 2005. Akuntansi Biaya. Edisi lima. Yogyakarta : UPP STIM YPKN.

Nugroho, Adi. 2005. Faktor-faktor yang Mempengaruhi Margin Pembiayaan Murabahah. Thesis. Jakarta :EkonomiKeuanganSyariah UI.

Riza , Abdah.2009. Aplikasi Pembiayaan Murabahah. Skripsi. Malang : FE UIN Malang.

Soedrajat, Setyo. 2004. Manajemen Pemasaran Jasa Bank. Cetakan Pertama. Jakarta : PT. Ikral

Mandiri Abadi.

Soemitra, Andri. 2009. Bank dan Lembaga Keuangan Syariah. Jakarta: Kencana Prenada Media Group.

Sulhan dan Ely. 2008. Manajemen Bank Konvensional dan Syariah. Edisi Pertama, Malang : UIN Malang Press.

Sutojo, Siswanto. 1997. Manajemen Terapan Bank. Cetakan Pertama. Jakarta : PT. Pustaka Binaman.

Tantowi, Ahmad. Pada 1 April 2012. Dalam http://kawansekawan.blogspot.com. Diunduh pada 12 Desember 2013.

Veithzal,Rivai, dkk. 2010. Islamic Financial Management. Edisi Pertama. Bogor :Penerbit Ghalia Indonesia.

Wiroso. 2005. Jual Beli Murabahah. Yogyakarta: UII Press 